\title{
The Two-Way Switch Role of ACE2 in the Treatment of Novel Coronavirus Pneumonia and Underlying Comorbidities
}

\author{
Xiao Cong Pang ${ }^{1,2,+}$, Han Xu Zhang ${ }^{2,+}$, Zhi Zhang ${ }^{3,+}$, Suguro Rinkiko ${ }^{1}$, Yi Min Cui ${ }^{2, *(\mathbb{D}}$ and Yi Zhun Zhu ${ }^{1,4, *}$ \\ 1 School of Pharmacy and State Key Laboratory for the Quality Research of Chinese Medicine, \\ Macau University of Science and Technology, Macau 999078, China; pangxiaocong1227@163.com (X.C.P.); \\ suguro_apple@foxmail.com (S.R.) \\ 2 Department of Pharmacy, Peking University First Hospital, Beijing 100034, China; zhanghanxu95@163.com \\ 3 School of Pharmaceutical Sciences, Tsinghua University, Beijing 100084, China; \\ zhangz2019@mail.tsinghua.edu.cn \\ 4 Shanghai Key Laboratory of Bioactive Small Molecules, Department of Pharmacology, School of Pharmacy, \\ Fudan University, Shanghai 201203, China \\ * Correspondence: cui.pharm@pkufh.com (Y.M.C.); yzzhu@must.edu.mo (Y.Z.Z.) \\ + These authors contributed equally to this work.
}

Citation: Pang, X.C.; Zhang, H.X.; Zhang, Z;; Rinkiko, S.; Cui, Y.M.; Zhu, Y.Z. The Two-Way Switch Role of ACE2 in the Treatment of Novel Coronavirus Pneumonia and Underlying Comorbidities. Molecules 2021, 26, 142. https://doi.org/ $10.3390 /$ molecules 26010142

Received: 17 November 2020 Accepted: 16 December 2020 Published: 31 December 2020

Publisher's Note: MDPI stays neutral with regard to jurisdictional clai$\mathrm{ms}$ in published maps and institutional affiliations.

Copyright: $\odot 2020$ by the authors. Licensee MDPI, Basel, Switzerland. This article is an open access article distributed under the terms and conditions of the Creative Commons Attribution (CC BY) license (https:// creativecommons.org/licenses/by/ $4.0 /)$.

\begin{abstract}
December 2019 saw the emergence of the coronavirus disease 2019 (COVID-19), caused by severe acute respiratory syndrome coronavirus-2 (SARS-CoV-2), which has spread across the globe. The high infectivity and ongoing mortality of SARS-CoV-2 emphasize the demand of drug discovery. Angiotensin-converting enzyme II (ACE2) is the functional receptor for SARS-CoV-2 entry into host cells. ACE2 exists as a membrane-bound protein on major viral target pulmonary epithelial cells, and its peptidase domain (PD) interacts SARS-CoV-2 spike protein with higher affinity. Therefore, targeting ACE2 is an important pharmacological intervention for a SARS-CoV-2 infection. In this review, we described the two-way switch role of ACE2 in the treatment of novel coronavirus pneumonia and underlying comorbidities, and discussed the potential effect of the ACE inhibitor and angiotensin receptor blocker on a hypertension patient with the SARS-CoV-2 infection. In addition, we analyzed the S-protein-binding site on ACE2 and suggested that blocking hot spot-31 and hot spot-353 on ACE2 could be a therapeutic strategy for preventing the spread of SARS-CoV-2. Besides, the recombinant ACE2 protein could be another potential treatment option for SARS-CoV-2 induced acute severe lung failure. This review could provide beneficial information for the development of anti-SARS-CoV-2 agents via targeting ACE2 and the clinical usage of renin-angiotensin system (RAS) drugs for novel coronavirus pneumonia treatment.
\end{abstract}

Keywords: severe acute respiratory syndrome (SARS); angiotensin-converting enzyme II (ACE2); renin-angiotensin system (RAS); lung injury; hypertension

\section{Introduction}

December 2019 saw the emergence of the coronavirus disease 2019 (COVID-19), caused by severe acute respiratory syndrome coronavirus-2 (SARS-CoV-2), which emerged in Wuhan, Hubei province, in central China, and spread rapidly across the globe [1,2]. Today, the outbreak constitutes a public health emergency of international concern (PHEIC). The SARS-CoV-2 outbreak is not only in China, but also throughout the rest of the world, as the number of infections continues to rise and the epidemic spreads to more countries. SARS-CoV-2 has a high similarity to bat coronaviruses, which has been postulated to be the primary source [3]. Current evidence suggests pangolins could be recognized as possible intermediate hosts and the transmission path of SARS-CoV-2 from pangolin to humans is being looked into [4].

Typical clinical features of SARS-CoV-2 infected patients are fever, dyspnea, dry cough, headache, and pneumonia, which are similar to the symptoms caused by human 
severe acute respiratory syndrome coronavirus (SARS-CoV) [5,6]. To prevent progress of respiratory distress, renal and hepatic failure, or even death, early intervention is crucial for confirmed cases [2,7,8]. So far, the death toll of the COVID-19 pandemic has surged to over 2000 in China. However, there are specific anti-virus drug therapies, and the high-infectivity/ongoing mortality rate of SARS-CoV-2 emphasizes the demand for drug discovery.

Full-genome sequencing and phylogenetic analysis suggested that SARS-CoV-2 is a distinct clade from the beta coronaviruses and shares a high sequence identity with SARS-CoV [3]. The entry of SARS-CoV into cells is mediated by the interaction between spike glycoprotein (S-protein) and the cellular receptor, which has been identified as angiotensin-converting enzyme 2 (ACE2) [9], homological to the angiotensin-converting enzyme (ACE) [10]. Due to the high homology with SARS-CoV, ACE2 was also considered a gateway for SARS-CoV-2. Moreover, it was reported that the binding affinity of the receptorbinding domain (RBD) of SARS-CoV-2 to ACE2 is 10-20 times stronger than that of SARSCoV RBD [11]. Most recently, the cryo-electron microscopy (cryo-EM) structure of SARSCoV-2 and full-length human ACE2-B0AT1 complex were analyzed [11,12]. These findings suggest ACE2 is a potential target for anti-SARS-CoV-2 agent development.

On the other hand, ACE2 is a critical negative regulator of renin-angiotensin system (RAS) [13], which exerts a series of protective effects in multiple organs. Notably, patients with severe SARS-CoV-2 are more likely to have underlying comorbidities, including hypertension, diabetes, cardiovascular disease, and cerebrovascular disease [2]. Inhibition of ACE2 may affect its important protective functions in the lung, kidney, and cardiovascular system. Herein, we reviewed the two-way switch role of ACE2 in the treatment of SARSCoV-2 pneumonia. This could be informative for targeting the ACE2 therapeutic strategy and the clinical application of RAS drugs for SARS-CoV-2 therapy.

\section{Function and Distribution of ACE2}

The ACE2 gene lays on chromosome Xp22 and contains 18 exons, many of which closely resemble exons in the ACE gene. Both ACE and ACE2 are type-I membrane-bound glycoprotein with a single carboxy-terminal extracellular domain, functioning as crucial regulator of the RAS and participating in the cleavage of a diverse set of substrates [14]. As shown in Figure 1, angiotensinogen generated in the liver is transformed into angiotensin I (Ang I) via the action of renin. Then, Ang I is converted to the potent vasoconstrictor angiotensin II (Ang II) by ACE, and Ang II plays important roles in vasoconstriction and aldosterone secretion predominantly through binding to the seven transmembrane G-protein-coupled receptor, named angiotensin receptor type 1 (AT1) [15]. Ang II can also induce vasodilatory effects by binding to angiotensin receptor type 2 (AT2), which has low levels of expression in the cardiovascular system [15]. Therefore, ACE inhibitors (ACEIs) and AT1 receptor blockers (ARBs) are applied for the treatment of cardiovascular diseases via blocking and/or reducing the adverse effects of Ang II [16].

ACE also exerts important effects on the kinin-kallikrein cascade. ACE converts the strong vasodilator bradykinin to bradykinin $1-5$, which is an inactive metabolite. Therefore, ACE is a prominent regulator in blood pressure through RAS and kinin-kallikrein as well $[17,18]$. ACE2 is homologous to ACE and plays a role in the transformation of Ang II to angiotensin-(1-7) (Ang 1-7), and also transforms Ang I to angiotensin(1-9) (Ang 1-9) [17,18]-meaning much lower efficiency than transformation to Ang 1-7 (Figure 1). Ang 1-7 is mainly generated from the conversion of Ang II by ACE2. Ang 1-7 binds to the Mas receptor, triggering intracellular signal transduction pathways [19]. Ang 1-7 exerts anti-hypertensive, anti-thrombotic, anti-fibrotic, and anti-inflammatory effects, which is opposed to the regulatory mechanism of Ang II [20-23] (Figure 1). Therefore, ACE and ACE2 could be considered to act as counterbalances in RAS. 
Kinin-kallikrein system

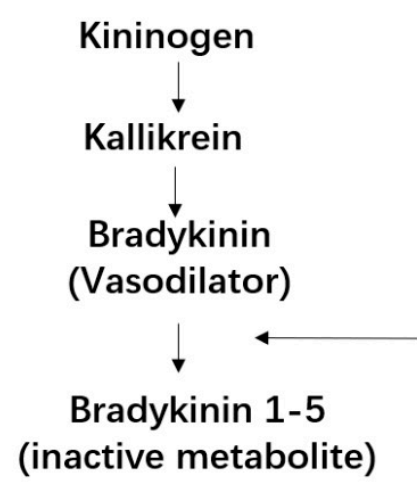

Renin-angiotensin system

Angiotensinogen

Renin

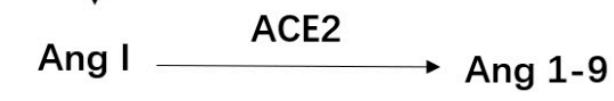

ACE

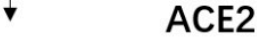

Ang II $\longrightarrow$ Ang 1-7

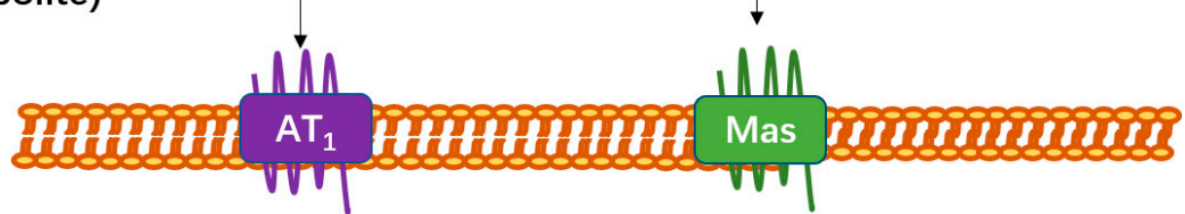

- Vasodilation

- Anti-hypertrophy

- Anti-proliferation

- Anti-inflammatory

- Anti-fibrosis

Figure 1. The regulatory mechanism of ACE and ACE2. ACE and ACE2 are both type I membrane- anchored zinc dipeptidyl carboxypeptidase responsible for the cleavage of multiple substrates, including vasoactive peptides. ACE and ACE2 could be considered to act as counterbalances in RAS. ACE participates in the production of the vasoconstrictor Ang II, exerting its effects by binding to G-protein coupled receptor named AT1. ACE2 engages in the conversion of Ang II to Ang 1-7 and Ang I to Ang 1-9, which is much lower efficiency than conversion to Ang 1-7. Ang 1-7 binds to the Mas receptor and a seven transmembrane G-protein-coupled receptor. Ang 1-7 produces vasodilation, anti-hypertensive, anti-proliferation, anti-inflammatory, and anti-fibrotic effects, which is opposed to the actions mediated by Ang II. ACE also exerts important effect on the kinin-kallikrein cascade. ACE converts the strong vasodilator bradykinin, to bradykinin 1-5, which is an inactive metabolite. Thus, ACE is a prominent regulator in blood pressure through RAS and kinin-kallikrein as well.

ACE2 exerts a series of protective effects in heart function, hypertension, diabetes, kidney, lung, and liver injury $[13,18,24,25]$. ACE2, as a membrane-bound ectoenzyme, is mainly localized on endothelial cells, and can be identified in tissues, including the kidney, liver, lungs, stomach, intestine, pancreas, testes, and so on $[25,26]$. SARS pathogen can trigger acute severe lung failure and acute respiratory distress syndrome (ARDS). ACE2, as a functional receptor for SARS-CoV-2, plays a critical role in SARS-induced lung injury $[27,28]$. ACE2 tissue distribution indicates some association with SARS-CoV-2 infection sites and disease pathology (Figure 2). Although compared with kidney and intestinal epithelia, ACE2 is moderately expressed in the lung, but respiratory symptoms are most severe [29]. SARS-CoV-2 mainly spreads via the respiratory tract, and type I and type II alveolar cells are the important sites of entrance for SARS-CoV-2, in particular, the abundant expression of ACE2 in type II pneumocytes may cause rapid viral expansion and local alveolar wall damage, resulting in further severe diffuse alveolar destruction [30]. Except for lungs, a SARS-CoV-2 infection also can extend to many organs, including the heart and blood vessels, kidney, liver, and the gut [27,30]. SARS-CoV-2 attacking the heart and blood vessels was widely reported that heart damage in nearly $20 \%$ of patients out of 416 hospitalized for SARS-CoV-2 in Wuhan, China, and 38\% SARS-CoV-2 infected patients out of 184 in a Dutch intensive care unit (ICU) had blood clots, which can break apart and land in the lungs, blocking vital arteries. ACE2 expression was mainly expressed on the surface of small intestinal epithelial cells [31]. More evidence suggested 
that SARS-CoV-2 can infect the lower gastrointestinal tract, where ACE2 expression is rich, and some $20 \%$ or more of patients have diarrhea $[27,30]$. ACE2 plays an important role in the regulation of dietary amino acid homeostasis, expression level of antimicrobial peptides, and gut microbial ecology [31]. Hashimoto T, et al. suggested that intestinal amino acid malnutrition via ACE2 can cause intestinal inflammation and diarrhea [31]. Different degrees of liver damage were implicated in SARS-CoV-2 infected patients, but its related mechanisms have not been clear. A recent study showed SARS-CoV-2 directly interacts with ACE2 expressed on cholangiocytes, but might not bind to hepatocytes [8]. Recently, it was suggested renal impairment is a common characteristic in SARS-CoV-2 infected patients, which may lead to multiple organ failure and lethal disease [32]. Hence, liver and renal function monitoring, and special care, should be performed in treating SARS-CoV-2 patients.
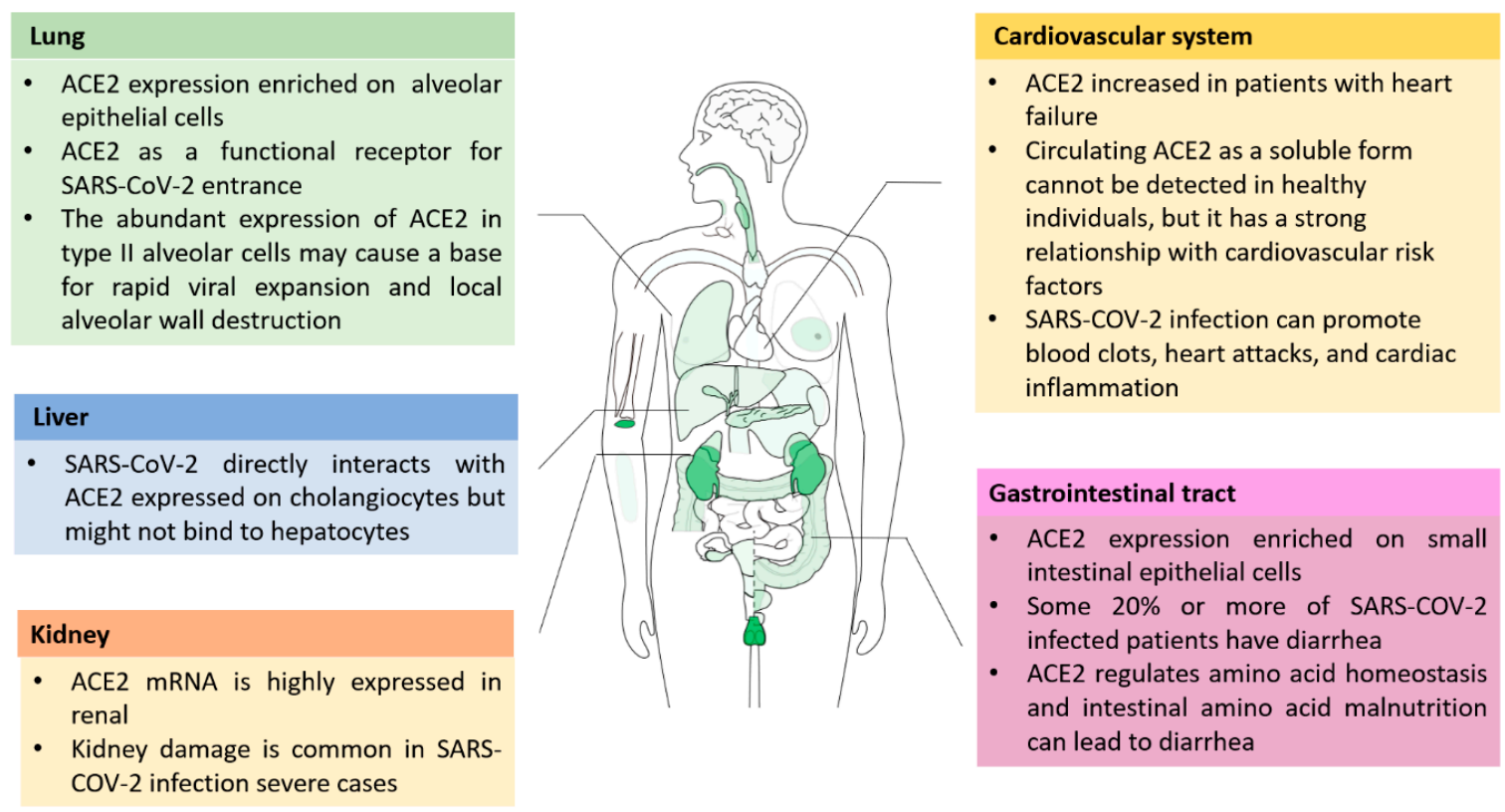

Figure 2. ACE2 tissue distribution and its potential association with severe acute respiratory syndrome coronavirus 2 (SARS-CoV-2) infection sites and disease pathology. ACE2 is mainly localized on endothelial cells and can be found in tissues, and among them kidneys, testis, and gastrointestinal tract, and have the highest ACE2 expressions. SARS-CoV-2 mainly spread via the respiratory tract, and type I and type II alveolar cells are the important sites of entrance for SARS-CoV-2, in particular, the abundant expression of ACE2 in type II pneumocytes may cause rapid viral expansion and local alveolar wall damage, resulting in further severe diffuse alveolar destruction. Except for the lungs, SARS-CoV-2 infection also can extend to many organs, including the heart and blood vessels, kidney, liver, and gut.

ACE2 is a functional receptor on cell surfaces for SARS-CoV-2 infection, it also sheds into the plasma as soluble form. The significant increase of circulating ACE2 is detected in the plasma of patients with cardiovascular disease, hypertension, diabetes, and chronic kidney disease [33-36]. The metalloproteinase ADAM metallopeptidase domain 17 (ADAM17 ) is responsible for mediating ACE2 shedding from the cell membrane-bound domain, which can be promoted by Ang II, and release the ACE2 soluble form in plasma [37]. Recently, it was reported that plasma soluble ACE2 in two large and independent cohorts with heart failure were higher in men than in women, and subjects with higher risk for severe SARS-CoV-2 had higher soluble ACE2, which suggested soluble ACE2 may be a marker of severity of SARS-CoV-2 [38].

More evidence, across countries, suggest the mortality rate from SARS-CoV-2 in men is higher than women, which indicates the presence of a potential sex-dependent susceptibility. ACE2 may participate in this different predisposition. The ACE2 gene is located on the $\mathrm{X}$-chromosome, so it gives females a potential heterozygosity compared to 
males, who are definitely hemizygous [14]. In females, X-heterozygous alleles can activate a mosaic advantage, as well as a greater sexual dimorphism, which may favor them when it comes to suppressing the SARS-CoV-2 infection and local inflammation leading to severe outcomes. In addition, SARS-CoV-2 receptor ACE2 and co-receptor transmembrane serine protease 2 (TMPRSS2) are co-expressed in prostate epithelial cells [39]. TMPRSS2 is highly expressed in human prostate epithelial cells and its regulation by androgen, which may lead to prostate susceptible to SARS-CoV-2 infection, and may be a biological risk factor for males. In addition, it was also reported that the androgen receptor (AR) can bind to the gene transcription promoter sequences of ACE2 and TMPRSS2, and androgen-AR activation may induce the expression of ACE2 and TMPRSS2 [40]. Dihydrotestosterone (DHT, AR activator) induces the expression of ACE2 and TMPRSS2 in activin-sensitive prostate cancer cells (LNCaP) and A549 non-small cell lung cancer cells, and GT0918 (a new generation of AR antagonists) can inhibit DHT-induced expression of ACE2 and TMPRSS2 [40]. These results indicate that AR plays a role in controlling the expression of ACE2 and TMPRSS2. However, this is primarily in experimental models, and there is still no conclusive evidence in humans.

\section{Inhibiting ACE2 to Block the Entry of Coronavirus}

\subsection{ACE2 as the Gateway of SARS-CoV-2}

ACE2 was considered as the functional and essential receptor for SARS-CoV infections. S-protein on the SARS-CoV regulates ACE2 receptor recognition and cellular membrane fusion [41]. In the phase of viral maturation, S-protein is cleaved into two separate subunits, S1 and S2, but for mature SARS-CoV virions, S-protein is not cleaved [42,43], whereas it still has two functional regions, S1 region and S2 region [9]. The RBD at the S1 region directly binds to ACE2 [3], and the S2 region participates in membrane fusion by priming by cellular protease. RBD of S1 region defined at residues 318-510 binding to ACE2 has a stronger affinity than the whole S1 region [9,42-44]. The alignment of the RBD from SARS-CoV-2 and SARS-CoV shows a 73.5\% sequence identity [11,12]. It was reported that the S-protein of SARS-CoV-2, the same as SARS-CoV, binds to ACE2 and extends into the pocket of the ACE2 catalytic domain [3,12]. As shown in Figure 3, the interaction of ACE2 and S-protein triggers virus particle endocytosis, further mediating the fusion of virus and host cytomembrane. S-protein priming not only employs endosomal cysteine proteases, but also utilizes the cellular serine protease TMPRSS2 on cell membrane. S-protein priming by host cell proteases play an essential role in viral membrane fusion [43-45]. The most recent studies suggested that TMPRSS2 was necessary for S-protein priming of SARS-CoV-2, and camostat mesylate, a serine protease inhibitor, could block the activity of TMPRSS2 [46-48]. ADAM-17 mediated shedding of ACE2 at the cell surface is an important pathological outcome of SARS-CoV-2 infection [49]. ADAM-17 activity is upregulated as the binding of SARS-CoV to ACE2 and contributes to viral entry [49]. TMPRSS2 was found to compete with the metalloprotease ADAM-17 for ACE2 ectodomain shedding. Cleavage of the C-terminal segment (especially residues 697-716) of ACE2 by TMPRSS2 enhances the S-protein-driven viral entry [50].

Although morbidity between men and women is approximately the same, more evidence across countries indicated the different susceptibility in men and women population. Recently, it was reported that an elevated androgen level increases the risk of SARS-CoV-2 susceptibility and severity in males. Androgen signaling inhibition reduces infectivity of SARS-CoV-2 in human embryonic stem cell (hESC)-derived lung organoids via decreasing the expression of ACE2 and TMPRSS2 levels [51]. 


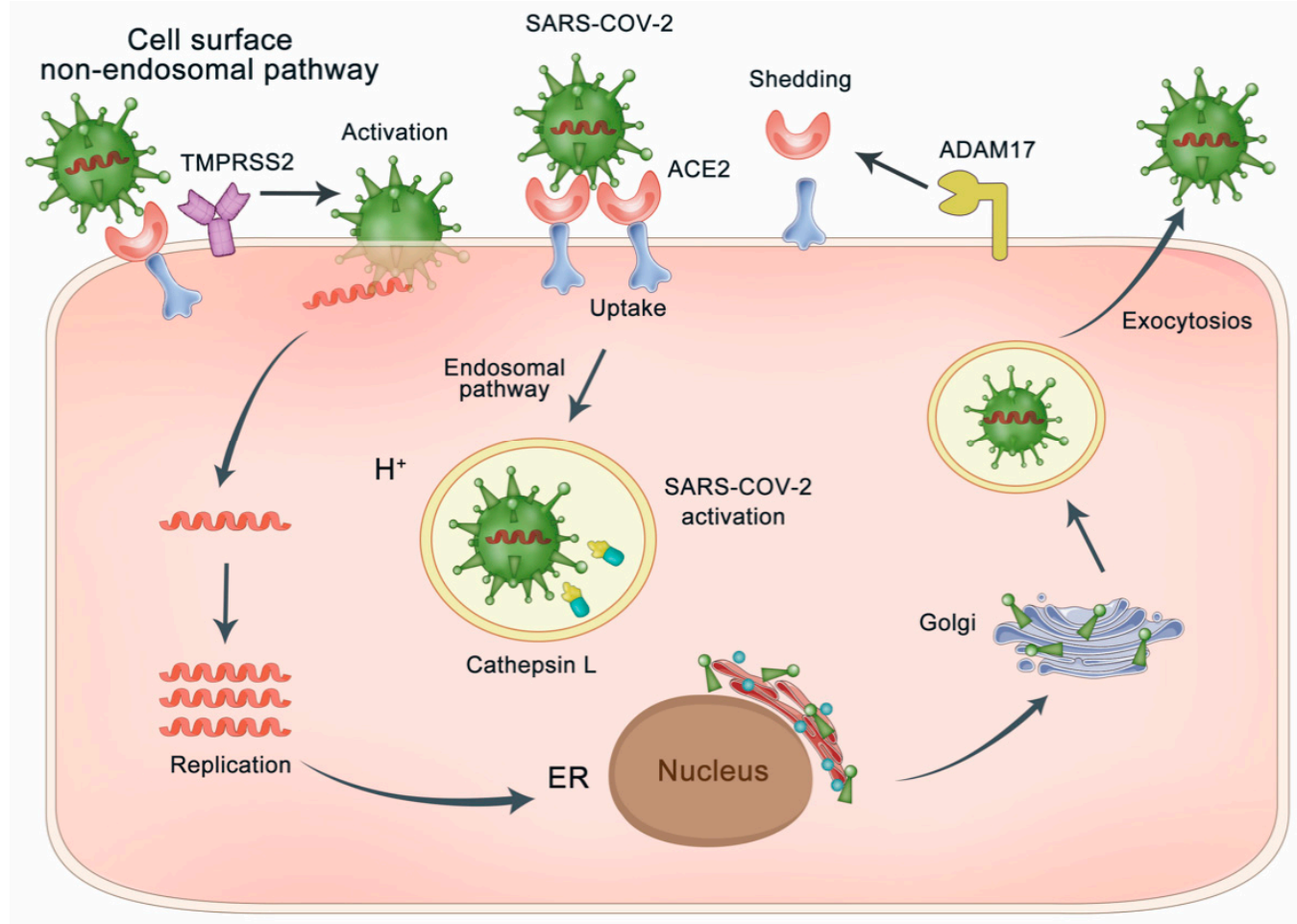

Figure 3. SARS-CoV-2 enters the host cell using the endosomal pathway and/or the cell surface non-endosomal pathway. The endosomal pathway is through ACE2-spike protein interaction, which triggers endocytosis of virus particles through internalization with the ACE2, further mediating the fusion of virus and host cells. In addition, the cell surface non-endosomal pathway for SARSCoV-2 spike protein priming by TMPRSS2 for viral entry into the cell. ADAM-17 mediated shedding of ACE2 at the cell surface is an important pathological outcome of SARS-CoV-2 infection. TMPRSS2 competes with the metalloprotease ADAM-17 for ACE2 ectodomain shedding. Cleavage of ACE2 by TMPRSS2 enhances the S-protein-driven viral entry.

\subsection{Blocking the Binding of S-Protein Binding Site of ACE2 with SARS-CoV-2}

The crystal structure of the ACE2 extracellular domains refers to peptidase domain (PD) and collectrin domain. In both SARS-CoV-2 and SARS-CoV, RBD of their S1 region is responsible for interaction with the PD of ACE2, and their interactive affinity was associated with the efficiency of virus infection [11,12]. The variation of RBD of S1 region changes may be important for the adaptive capacity of SARS-CoV-2 and SARS-CoV to infect human cells. In particular, during the 2002-2003 SARS-CoV outbreak, alteration of residues 479 and 487 at RBD proved to be critical to the interactive affinity with human ACE2 via binding to two virus-binding hotspots 31 and 353 on ACE2, center on Lys 31 and Lys353, respectively $[52,53]$. The hotspots are critical for coronavirus binding as they involve two lysine residues that need to be accommodated properly in hydrophobic environments. Lys31 and Lys353 can form a salt bridge with Glu35 and Asp38, respectively, hidden in the hydrophobic environment [53,54].

Most recently, the receptor recognition by SARS-CoV-2 was also analyzed [12,50,55]. The overall structure of the SARS-CoV-2/ACE2 complex is very similar to the previously reported structure of SARS-CoV interaction with ACE2 [55]. Compared with the SARSCoV RBD, the two virus-binding hotspots (hot spot-31 and hotspot-353) at the RBD/ACE2 interface are more stabilized due to several residue changes in SARS-CoV-2 RBD [50]. In particular, Gln493 and Leu455 of SARS-CoV-2 RBD stabilizes hotspot-31, and Asp501 of SARS-CoV-2 RBD stabilizes hotspot-353, respectively [50]. In addition, compared with SARS-CoV, four-residue motif (residues 482-485: Gly-Val-Glu-Gly) of SARS-CoV-2 RBD contains structural changes in the ACE2-binding ridge to become more compact interaction with the N-terminal helix of ACE2 [50]. Moreover, the replacement of Val404 to Lys317 
in SARS-CoV-2 RBD may lead to tighter association because of the salt bridge formation between Lys317 and Asp30 of ACE2 [12]. The change from Leu472 to Phe486 appears to make stronger van der Waals contact with Met82 [12].

ACE2 activity can be inhibited by metallopeptidase inhibitor, MLN-4760, in the low nanomolar range, and lose its enzymatic activity in the concentration of $100 \mathrm{nM}$ inhibitor, but 100 nM MLN-4760 did not have influence on S-protein-induced infection [56]. Towler et al. also reported that the distance alteration among $\alpha$ helix 1 and $\beta$-sheet 5 of key residues on S-protein-binding site is less than $0.4 \mathrm{~A}^{\circ}$ with or without inhibitor bounded [56]. Therefore, the interaction of S-protein with ACE2 is not disturbed by ACE2 inhibitors or substrates induced conformational alteration. Moreover, the enzymatic activity of ACE2 does not be interfered with by S-protein binding [52].

Recently, the glycosylation sites were considered important for receptor recognition and virus entry $[12,52]$. In the vicinity of the RBD, three glycosylation sites on PD were observed, including Asn90, Asn322, and Asn53 [12]. It was reported that chloroquine can inhibit SARS-CoV infection via interfering with ACE2 terminal glycosylation [57]. It was still not clear about the specific engagement of sugar moieties in S-protein binding. Taken together, targeting ACE2 at S-protein-binding site, especially hot spot-31 and hot spot-353, is a potential strategy for inhibiting the entry of SARS-CoV-2. Based on molecular docking and structure-activity study, Huentelman MJ, et al. identified a novel ACE2 inhibitor, NAAE ( $N$-(2-aminoethyl)-1 aziridine-ethanamine), could modulate ACE2 catalytic activity, and inhibit SARS-CoV S-protein-mediated cell fusion in vitro [58]. On account of the critical segments of ACE2, analogous peptide comprised of two discontinuous segments of ACE2 (a.a. 22-44 and 351-357) artificially linked together by glycine, were synthesized and evaluated, which also exhibited potent anti-SARS-CoV activity in vitro with the half maximal inhibitory concentration $\left(\mathrm{IC}_{50}\right)$ of about $0.1 \mathrm{mM}$ [9]. Recently, it was reported that SARS-CoV-specific human monoclonal antibody, CR3022, could bind potently with SARSCoV-2 RBD with the calculated affinity $\left(\mathrm{K}_{\mathrm{D}}\right)$ of $6.3 \mathrm{nM}$ [59]. Considering the difference in the RBD of SARS-CoV and SARS-CoV-2, it is still necessary to develop novel small molecules or monoclonal antibodies that could bind specifically to SARS-CoV-2 RBD.

\section{Activating the Peptidase Function of ACE2 for Lung Protection}

\subsection{ACE2 Functions as a Negative Regulator of RAS}

Due to the fact that ACE2 counterbalances the effect of Ang II, ACE2 has been considered a negative regulator in RAS. Cardiac contractility defects were observed in ACE2 knockout mice, accompanied by the increase of Ang II [18]. The deficiency of ACE2 also resulted in the inflammatory response in the myocardial infarction regions, triggering neutrophilic infiltration, increasing of interferon $\gamma$ (IFN $\gamma$ ), and interleukin-6 (IL-6), and activating the downstream extracellular signal-regulated kinase $1 / 2$ (ERK1/2) and c-Jun N-terminal kinase 1/2 (JNK1/2) pathways [60]. ACE2 also exerts protective effects in renal disease through inhibiting oxidative stress, renal inflammation, and fibrosis [61].

Emerging evidence showed the protective role of ACE2 in lung pathophysiology was associated with attenuating RAS. ACE-2 cleaves Ang II to generate Ang 1-7 and thereby limits Ang II accumulation. By reducing the level of Ang II, ACE2 exerts protective effect on lung injury and lung fibrosis [13]. In lung biopsy samples from idiopathic pulmonary fibrosis (IPF) patients, ACE2 mRNA level and enzyme activity were severely decreased, which showed similarly in the lungs of bleomycin-treated rats and C57-BL6 mice [62]. With intratracheal administration of a competitive inhibitor of ACE2, peptide DX600, or ACE2-specific siRNAs, the profibrotic peptide Ang II level increased and the experimental lung fibrosis was enhanced [62]. Purified recombinant human ACE2 systemically attenuated bleomycin-induced lung fibrosis and restrained the progression of lung injury in ACE2 knockout mice [62,63]. Moreover, the upregulation of ACE2 attenuates pulmonary arterial hypertension (PAH) [64], bleomycin-induced pulmonary fibrosis [63]. Except for chronic lung disease, ACE2 is also a protective regulator in acute lung injury (ALI) and respiratory distress syndrome. In the lipopolysaccharide (LPS)-induced ALI models, the 
expression of ACE2 was reduced, which caused inflammatory injury and lung pathological injury via abnormal activation of toll-like receptor 4 (TLR4) pathway [64]. After intratracheal administration of recombinant ACE2, lung function and inflammatory injury were significantly recovered, accompanied by inhibition of TLR4 pathway [65]. ACE2 not only plays an important role in a SARS coronavirus-induced lung injury, but also in lethal avian influenza A (H5N1, H7N9) induced ALI [66,67]. Yang P.H., et al. reported that H7N9 virusinduced ALI leads to the remarkable downregulation of ACE2, further aggravating lung pathogenesis markedly [67]. These investigations proved the protective roles of ACE2 in lung pathophysiology. Therefore, recombinant soluble ACE2 could be a potential therapy option for acute lung injury, which is now being tested in clinical trials $[68,69]$.

\subsection{Stimulating the Expression of ACE2}

Transcriptional regulation of ACE2 could be effected dynamically under different physiological and pathological conditions (Table 1). Although transcriptional regulation of ACE2 is still unclear, accumulating evidences suggested that Ang II was able to upregulate ACE and downregulate ACE2 [70]. It was reported that the AT1 receptor-mediated $\mathrm{ERK} / \mathrm{p} 38$ mitogen-activated protein (MAP) kinase signaling pathway contributed to the downregulation ACE2 expression-induced Ang II, indicating an ACE/ACE2 imbalance in cardiovascular and renal injury [70]. The nuclear factor- $\mathrm{KB}(\mathrm{NF}-\mathrm{\kappa B})$ signaling pathway is also a key mechanism by which Ang II downregulates ACE2 expression [71]. The relationship between ARBs and ACE2 has been widely investigated, indicating that olmesartan, losartan, telmisartan, and azilsartan could increase the ACE2 mRNA or protein expression levels in animal models of heart diseases [72]. In patients with chronic kidney disease, it was suggested that olmesartan showed unique effects on the upregulation of urinary ACE2 level, which could preserve or improve of renal functions [73]. There are poor reports that ACEIs affect the expression of ACE2 in the heart and the kidney [74-77]. In normal rats, lisinopril has been shown to modestly increase cardiac ACE2 mRNA levels, while in the myocardial infarction model, valsartan, ramipril, and their combination have no effects on cardiac ACE2 expression [32]. However, enalapril could attenuate downregulation of ACE2 in myocardial infarcted rats [74] and prevent cardiac hypertrophy and dysfunction. It should be noted that no clinical data exist regarding the effects of ARBs and ACEIs on human tissue ACE2 expression or activity in vivo [75-77].

Except for RAS, the mineralocorticoid receptor blockade (e.g., spironolactone) exerted its beneficial effects by suppressing oxidative stress and increasing ACE2 mRNA in macrophage by increasing the generation of Ang 1-7 and decreasing the formation of Ang II [78]. Recent evidence has suggested that vitamin D, a fat-soluble-vitamin, plays an essential role in the immune response against viral infections, and indicated vitamin $\mathrm{D}$ is a negative endocrine RAS modulator [79-81]. It can induce ACE2/Ang-(1-7)/MasR axis activity and inhibit renin and the ACE/Ang II/AT1R pathway, thereby upregulating expression level of ACE2, MasR, and Ang-(1-7), and exerting a potential protective role against ALI and ARDS [81]. Vitamin D deficiency also increases susceptibility to viral infections as well as the risk of recurrent infections [80]. Therefore, vitamin D may be a potential therapeutic approach to combat SARS-CoV-2 infection induced ARDS [80,81].

In addition to Ang II, apelin is another catalytic substrate for ACE2 and is considered an inotropic and cardioprotective peptide [82,83]. Among apelin peptides, apelin-13 is the most abundant in human plasma and cardiac tissue, and it exists predominantly under its pyroglutamylated form (Pyr-apelin-13) [84]. ACE2 could cleave and inactivate Pyr-apelin-13. In ACE2 knockout mice, hypotensive action of Pyr-apelin-13 was enhanced, with higher apelin levels in plasma. In turn, apelin-13, via activation of $\mathrm{G}$ protein-coupled receptor, the apelin receptor (APJ), increased ACE2 promoter activity in vitro, and upregulated ACE2 expression in failing hearts in vivo [83]. Moreover, apelin-13 treatment also increased cardiac contractility and ACE2 levels in AT1R-deficient mice, which demonstrate an antagonistic relationship between the RAS and apelin [83]. 
Table 1. The regulation of angiotensin-converting enzyme 2 (ACE2) by different mediators.

\begin{tabular}{|c|c|c|c|}
\hline Mediator & $\begin{array}{l}\text { Effect on ACE2 } \\
\text { Expression }\end{array}$ & Pathway & Associated Disease \\
\hline $\begin{array}{l}\text { AT1 receptor blockers, } \\
\text { such as olmesartan, } \\
\text { losartan, telmisartan, } \\
\text { azilsartan }\end{array}$ & Upregulation & $\begin{array}{c}\text { Renin-angiotensin system; } \\
\text { extracellular-signal-regulated } \\
\text { kinase/mitogen-activated protein kinase } \\
\text { (ERK/MAPK) signaling pathway; nuclear } \\
\text { factor- } \mathrm{kB}(\mathrm{NF}-\mathrm{kB}) \text { signaling pathway }\end{array}$ & $\begin{array}{c}\text { Acute lung injury, } \\
\text { hypertensive cardiovascular } \\
\text { and renal damage }\end{array}$ \\
\hline $\begin{array}{l}\text { ACE inhibitors, such } \\
\text { as Lisinopril, Enalapril }\end{array}$ & Downregulation & Renin-angiotensin system & Myocardial infarction \\
\hline Vitamin D & Upregulation & Renin-angiotensin system & $\begin{array}{c}\text { Acute lung injury (ALI) } \\
\text { Acute respiratory distress } \\
\text { syndrome (ARDS) }\end{array}$ \\
\hline Spironolactone & Upregulation & NADPH oxidase related pathway & Heart failure \\
\hline Resveratrol & Upregulation & $\begin{array}{l}\text { alpha-amino-3-hydroxy-5-methyl-4-isoxazole } \\
\text { propionic acid (AMPA) signaling pathway }\end{array}$ & $\begin{array}{l}\text { Diabetes mellitus, cardiac } \\
\text { fibrosis and heart disease }\end{array}$ \\
\hline Apelin-13 & Upregulation & $\begin{array}{l}\text { Apelin-the apelin receptor (APJ) } \\
\text { activation pathway }\end{array}$ & Cardiovascular diseases \\
\hline Interleukin-1 $\beta$ (IL-1 $\beta$ ) & Upregulation & \multirow{2}{*}{ Cytokine signaling pathway } & $\begin{array}{l}\text { SARS coronavirus } \\
\text { diabetes mellitus }\end{array}$ \\
\hline $\begin{array}{l}\text { Interferon } \alpha(\operatorname{IFN} \alpha) \text {, } \\
\text { Interferon } \gamma(\operatorname{IFN} \gamma)\end{array}$ & Downregulation & & SARS coronavirus \\
\hline Interleukin-4 (IL-4) & Downregulation & & SARS coronavirus \\
\hline
\end{tabular}

There also exists other molecules in the transcriptional regulation of ACE2 level. Sirtuin 1 (SIRT1) could regulate ACE2 level via AMP-activated protein kinase (AMPK) signals and this role might be beneficial to their protective role against cellular stress in type 2 diabetes mellitus (T2DM), diabetic nephropathy, and myocardial injury [85,86]. Resveratrol has multiple beneficial activities, including antioxidant, anti-inflammatory, and cardioprotective effects [87]. It was reported that resveratrol administration could increase SIRT1 and ACE2 protein expression to reduce oxidative stress and modulate of RAS [88]. The cytokines showed different functions in regulating the expression of ACE2. IL-1 $\beta$ upregulated ACE2 transcription, in ARDS, IL-1 $\beta$ exerted protective effects and promoted epithelial repair, which was likely referred to the regulation of ACE2 in several inflammatory conditions [85]. Whereas, IL-4 downregulated expression of the SARS-CoV receptor ACE2 in Vero E6 cells [89]. The downregulation of ACE2 expression through addition of IL-4 might suggest a novel antiviral strategy against SARS-CoV infection. ACE2 was recently reported to be a human interferon stimulated gene (ISG) in airway epithelial cells [90]. Interferon a (IFN $\alpha)$, and to some extent IFN $\gamma$, led to the upregulation of ACE2 expression in the main human upper airway cells [90]. As SARS-CoV-S caused ACE2-receptor-mediated internalization, the host IFN response could enhance the capability for SARS-CoV and SARS-CoV-2 to maintain cellular targets in the near upper airway epithelial cells [90], which indicated the clinic usage of IFN $\alpha$ might aggravate the SARS-CoV-2 infection.

\subsection{The Clinical Usage of ACEIs and ARBs for SARS-CoV-2 Infected Patient with Cardiovascular Diseases: Pros and Cons}

In a descriptive study of the 99 patients with SARS-CoV-2 pneumonia, $50(51 \%)$ patients had chronic diseases, and $40(40 \%)$ patients had cardiovascular and cerebrovascular diseases [91]. Given that ACE2 is a gateway for SARS-CoV-2, binding of the SARS-CoV-2 virus to its ACE2 appears to lead to an imbalance in RAS signaling: a decrease in beneficial products derived from ACE2 relative to enhance the potentially harmful effects from Ang II/AT1R1 action. In particular, the dysregulation of RAS is recognized as a main factor in the progression of cardiovascular pathologies [92,93], so the problems of ACEIs or ARBs 
administration for SARS-CoV-2 infected patients with cardiovascular diseases are subject to address in clinical practice.

Because ACE and ACE2 exhibits structural difference in their active site, classical ACE inhibitor cannot inhibit the activity of ACE2 [94]. On the one hand, it was suggested that ACE or AT1R inhibitors could still be used for SARS-CoV-2 infected patients with cardiovascular diseases. Firstly, pathological findings of SARS-CoV-2 were related to ARDS [95], and the clinical symptoms of SARS-CoV-2 were highly similar to those of SARS coronavirus infection [96,97]. The upregulation of Ang II mediated by ACE was observed in ARDS pathogenesis, which caused severe lung failure via the interaction of Ang II with AT1 receptor [63]. Therefore, AT1R or ACE blockade alleviated pneumonic injury. Secondly, in the lung failure caused by SARS-CoV, the level of ACE2 protein is decreased, but ACE levels are normal [28]. Due to ACE2 as a key negative regulatory factor for acute lung injury, SARS-CoV-induced ACE2 downregulation increase Ang II level, which leads to the severity of lung pathologies [28]. In Spike-Fc-treated mice, ACE2 was pulled down, and its expression was downregulated, while AT1R inhibitors could rescue acute severe lung injury [28]. Hence, SARS-CoV-induced lung injury can be attenuated by AT1R inhibitor. Flow cytometric analysis of peripheral blood of SARS-CoV-2 infected patients implied T cell overactivation with the upregulation of Th17 [95]. The selective antagonist of the AT1 receptor, losartan, prevents the development of ARDS triggered by lung bacterial infection through suppressing the activation of neutrophils by $\mathrm{N}$-formylmethionyl-leucylphenylalanine (fMLP) [98].

On the other hand, some clinicians suggested that although ACE2 is insensitive to ACE inhibitors, ACE inhibition or AT1 receptor blockade increased ACE2 gene expression or activity in cardiac and vascular tissue $[99,100]$. Actually, in the context of renal cortex, ACE2 expression remained unchanged with ACE inhibition or AT1 receptor blockade, but its activity increased with the administration of lisinopril or losartan alone [101]. The same therapeutic agents with the same dose administrated to the same rate for the same period caused varied consequences on ACE2 expression and activity in cardiac and renal tissue [101]. Taken together, these findings suggested a tissue-specific regulation of ACE2 expression under ACE inhibition or AT1 receptor blockade that affects the generation of Ang II [26,101]. Therefore, the ACE or AT1R blockers did not necessarily upregulate ACE2 expression in the lungs, and there was not enough reasons to stop taking ACE or AT1R inhibitors for SARS-CoV-2 infected patients with cardiovascular diseases.

ACEIs and ARBs are differently related to ACE2: ACEIs inhibit ACE in the transformation of Ang I to Ang II and, consequently, reduce pro-inflammatory Ang II production, and potentially decrease the generation of Ang 1-7. However, ARBs through blocking the Ang II interacted with AT1R could divert a larger proportion of generated Ang 1-7 towards ACE2, and increase the generation of Ang 1-7 level, which produces vasodilation, anti-hypertensive, anti-proliferation, anti-inflammatory, and anti-fibrotic effects. Therefore, multiple clinical trials (NCT04335786, NCT04355936, NCT04332666, NCT04312009, NCT04311177, NCT04328012, and NCT04340557) have recently proposed the tentative use of ARBs, such as telmisartan, valsartan, and losartan, as alternative options for treating SARS-CoV-2 patients (Table 2). In these clinical trials, there were some inconformity in the study design, including inclusion and exclusion criteria, dose selection, outcomes management, and biomarkers selection. Virus spike protein binds to ACE2 to form a complex suitable for cellular internalization, which leads to a partial decrease or total loss of the enzymatic function of ACE2 in the alveolar cells, and in turn upregulates the tissue concentration of pro-inflammatory Ang II by reducing its degradation and reducing the concentration of its physiological antagonist Ang 1-7. High levels of Ang II on the lung interstitium can promote apoptosis, initiating a self-powered cascade with release of proinflammatory cytokines, leading eventually to ARDS. Therefore, available AT1R blockers have the potential to block this pathological process mediated by Ang II and the excessive angiotensin-mediated AT1R activation. AT1R blockers may suppresses the development of ARDS and reduce morbidity (admission to ICU) and mortality. Besides ACE or AT1R 
blockers, there also existed other therapies related to the RAS pathway. Inhaled delivery of ACEIs / ARBs is a potential alternative for the treatment of RAS-mediated acute lung injury in SARS-CoV-2 infected patients [102]. Administration of ANG 1-7 (or TXA127, a purified formulation of ANG 1-7) activating the G protein-coupled receptor Mas (MAS1) or AVE 0991 (nonpeptide MAS1 agonist) could also be considered for SARS-CoV-2 infection with pulmonary damage [102].

Except for focusing on new antiviral agents for SARS-CoV-2 infection, therapeutics that target clinical manifestations, referring to tissue damage, should also be emphasized. ACEIs and ARBs are potential treatments for preventing those complications, and the benefit and risks of these drugs should be assessed in randomized controlled trials. The preclinical studies should also be carried out to elucidate the roles of the RAS pathway in SARS-CoV-2 pathobiology and develop potential RAS-targeted therapeutic strategies.

Table 2. Clinical trials evaluating the efficacy of ACE2-ralated therapy and RAS drugs in SARS-CoV-2 pneumonia treatment.

\begin{tabular}{|c|c|c|c|}
\hline $\begin{array}{l}\text { Clinical Trials } \\
\text { Identifier }\end{array}$ & Study Title & Interventional Drug & Interventional Study Design \\
\hline NCT04351581 & $\begin{array}{l}\text { Combination of Recombinant Bacterial } \\
\text { ACE2 Receptors -Like Enzyme of } \\
\text { B38-CAP and Isotretinoin Could be } \\
\text { Promising COVID-19Infection- and Lung } \\
\text { Injury Preventing Drug Better Than } \\
\text { Recombinant Human ACE2 }\end{array}$ & $\begin{array}{l}\text { rbACE2 plus } \\
\text { Aerosolized } \\
\text { Isotretinoin }\end{array}$ & $\begin{array}{l}\text { Randomized } \\
\text { Parallel Assignment } \\
\text { Open Label }\end{array}$ \\
\hline NCT04355936 & $\begin{array}{l}\text { Telmisartan for Treatment of } \\
\text { COVID-19 Patients }\end{array}$ & Telmisartan & $\begin{array}{l}\text { Randomized } \\
\text { Parallel Assignment } \\
\text { Open Label }\end{array}$ \\
\hline NCT04335786 & $\begin{array}{l}\text { Valsartan for Prevention of Acute } \\
\text { Respiratory Distress Syndrome in } \\
\text { Hospitalized Patients with SARS-CoV-2 } \\
\text { (COVID-19) Infection Disease }\end{array}$ & Valsartan & $\begin{array}{c}\text { Randomized } \\
\text { Parallel Assignment } \\
\text { Quadruple (Participant, Care Provider, } \\
\text { Investigator, Outcomes Assessor) }\end{array}$ \\
\hline NCT04312009 & $\begin{array}{l}\text { Losartan for Patients with COVID-19 } \\
\text { Requiring Hospitalization }\end{array}$ & Losartan & $\begin{array}{c}\text { Randomized } \\
\text { Parallel Assignment } \\
\text { Quadruple (Participant, Care Provider, } \\
\text { Investigator, Outcomes Assessor) }\end{array}$ \\
\hline NCT04311177 & $\begin{array}{l}\text { Losartan for Patients with COVID-19 Not } \\
\text { Requiring Hospitalization }\end{array}$ & Losartan & $\begin{array}{c}\text { Randomized } \\
\text { Parallel Assignment } \\
\text { Quadruple (Participant, Care Provider, } \\
\text { Investigator, Outcomes Assessor) }\end{array}$ \\
\hline NCT04328012 & $\begin{array}{l}\text { COVID MED Trial-Comparison of } \\
\text { Therapeutics for Hospitalized Patients } \\
\text { Infected with SARS-CoV-2 }\end{array}$ & $\begin{array}{c}\text { Losartan } \\
\text { combined with } \\
\text { lopinavir/ritonavir }\end{array}$ & $\begin{array}{c}\text { Randomized } \\
\text { Parallel Assignment } \\
\text { Double blind, placebo controlled }\end{array}$ \\
\hline NCT04340557 & $\begin{array}{l}\text { Do Angiotensin Receptor Blockers } \\
\text { Mitigate Progression to Acute } \\
\text { Respiratory Distress Syndrome with } \\
\text { SARS-CoV-2 Infection }\end{array}$ & Losartan & $\begin{array}{l}\text { Randomized } \\
\text { Parallel Assignment } \\
\text { Open Label }\end{array}$ \\
\hline NCT04332666 & $\begin{array}{l}\text { Angiotensin-(1,7) Treatment in } \\
\text { COVID-19: the ATCO Trial (ATCO) }\end{array}$ & Angiotensin 1-7 & $\begin{array}{c}\text { Randomized } \\
\text { Parallel Assignment } \\
\text { Triple (Participant, Investigator, } \\
\text { Outcomes Assessor) }\end{array}$ \\
\hline
\end{tabular}

\section{Control of the Two-Way Switch of ACE2 in SARS-CoV-2 Infection and Its Underlying Comorbidities}

Compared with SARS-CoV, SARS-CoV-2 had comparable transmissibility, which may depend on high affinity to a virus-binding host cell receptor, ACE2, and interaction with host cell protease-cleaving virus S-protein. Because ACE2 is a functional receptor in SARS-CoV-2 infection, targeting ACE2 may be a potential antiviral treatment option for 
SARS-CoV-2 infection. Ideal ACE2 inhibitor or peptides should act on the S-protein-binding site, and not reduce the peptidase activity of ACE2 for processing Ang II to Ang-(1-7). Therefore, the potential effect of ACE2 inhibitor on RAS should be evaluated, and the level of plasma Ang II level should be determined to prevent the adverse drug reaction related to lung injury, and cardiovascular and kidney disease. Given that SARS-CoV-2 spread depends on ACE2 for entry and TMPRSS2 for S-protein priming, and the co-expression of ACE2 and TMPRSS2 on the same virus target cells [103], like lung AT2 cells, dual blockage of TMPRSS2 and ACE2 could be promising treatment for SARS-CoV-2 infection.

SARS-CoV-2 infection can trigger a cytokine storm and induce autoimmune-related damages. The increase of ACE2, further mediating the upregulation of Ang 1-7 levels and decrease of Ang II, suggested being protective against lung injury. ACE2 has been shown to modulate innate immunity and decrease the level of pro-inflammatory cytokines [13]. Recombinant human ACE2 protein, therefore, can protect individuals with SARS-CoV-2 from developing acute severe lung failure and acute respiratory distress syndrome. Recently, it was reported that SARS-CoV-2 infection could be significantly inhibited by human ACE2 protein in human blood vessel organoids and kidney organoids models, and human ACE2 can neutralize virus pseudotyped with SARS-CoV-2 spike proteins in vitro, which indicates that human ACE2 protein might block the earlier entry of SARS-CoV-2 [104]. Considering that the lung is the major target, lung organoids should also be taken to assess the further protective effects. Further clinical studies are needed to reveal the effect of human ACE2 protein in SARS-CoV-2 infections. The clinical trials of recombinant human ACE2 refers to APN01 (NCT00886353) and GSK2586881 (NCT01597635), which completed the Phase I and Phase II study, respectively. In Phase II, for investigating the intravenous administration of GSK2586881 in patients with acute respiratory distress syndrome, the safety and efficacy were confirmed for its (well) toleration with a wide range of doses, and ACE2-mediated rapid transformation of Ang II to Ang 1-7, as well as tendency to reduce IL-6 levels $[105,106]$. Because recombinant ACE2 may compete with AT1R for Ang II, the balance of RAS is likely to be influenced by an excess of recombinant ACE2, which is important for the clinical success of recombinant human ACE2. Recombinant human ACE2 is a glycosylated protein, and thus its preparation requires a time- and cost-consuming protein expression system with mammalian or insect cells. A randomized, open label, controlled clinical study of recombinant bacterial ACE2 receptors, B38-CAP, were registered in ClinicalTrials.gov (NCT04351581) to evaluate the therapeutic effect of SARS-CoV-2 infection and lung injury. B38-CAP is a bacteria-derived ACE2-like enzyme that downregulates Ang II levels in mice and suppresses Ang II-induced hypertension, pathological cardiac hypertrophy, and myocardial fibrosis [107]. Treatment with an ACE2-like enzyme in bacteria B38-CAP might be do the same mechanism of rhACE2 in inhibiting SARS-CoV-2 infection [107]. Recently, it was indicated that ACE2 mutations in the N-glycosylation motif (N90 and T92) and buried hydrophobic sites that might have better effects on plasma membrane trafficking could increase $S$ binding, which provides a novel way to increase the affinity to SARS-CoV-2 [108].

In conclusion, ACE2 is a functional receptor in SARS-CoV-2 infection, and it has a high affinity with RBD of the SARS-CoV-2 S-protein. Blocking the S-protein-binding site, especially on hot spot-31 and hot spot-353, with ACE2-derived peptides or small molecule inhibitors, could be a potential treatment option. In addition, a recombinant ACE2 protein could be another treatment option for SARS-CoV-2 infection related severe lung failure and acute respiratory distress syndrome [109]. In SARS-CoV infection, ACE2 was downregulated, further activating the RAS and increasing Ang II, resulting in pathogenesis of acute lung injury or severe ARDS. The molecular relationship between SARS-CoV-2 infection and the expression of ACE2, the role of the RAS in lung failure should be further investigated. In addition, the safety and efficacy of ACE2 inhibitors or recombinant ACE2 protein in patients with SARS-CoV-2 infection also needs to be further evaluated in the preclinical and clinical study. 
Author Contributions: X.C.P., Y.Z.Z. and Y.M.C. designed the structure of the article and collected the main reference; Z.Z. and H.X.Z. draw the figures and prepared the tables. X.C.P. and S.R. analyzed the data. X.C.P. and H.X.Z. wrote the manuscript. All authors have read and agreed to the published version of the manuscript.

Funding: This work was supported by the National Key R\&D Program of China, No. 2016YFC0904900; National Natural Science Foundation (No. 81973320, No. 81673509, No. 81573504, and No. 81903714) of PR China; Beijing Municipal Natural Science Foundation (No. 7171012 and No. 7204317); scientific research fund of Peking University First Hospital (No.2019SF05, and No.2019CR19); and Macau Science and Technology Development fund (FDCT (067/2018/A2, 033/2017/AMJ, and 0007/2019/AKP, and $0052 / 2020 / A)$ ).

Conflicts of Interest: The authors declare no conflict of interest.

\begin{tabular}{|c|c|}
\hline \multicolumn{2}{|c|}{ Abbreviations } \\
\hline COVID-19 & coronavirus disease 2019 \\
\hline SARS & severe acute respiratory syndrome \\
\hline SARS-CoV-2 & severe acute respiratory syndrome coronavirus- 2 \\
\hline PHEIC & public health emergency of international concern \\
\hline S-protein & spike glycoprotein \\
\hline ACE2 & angiotensin-converting enzyme 2 \\
\hline ACE & angiotensin-converting enzyme \\
\hline RBD & receptor-binding domain \\
\hline cryo-EM & cryo-electron microscopy \\
\hline RAS & renin-angiotensin system \\
\hline Ang I & angiotensin I \\
\hline Ang II & angiotensin II \\
\hline AT1 & angiotensin receptor type 1 \\
\hline AT2 & angiotensin receptor type 2 \\
\hline ACEIs & ACE inhibitors \\
\hline ARBs & AT1 receptor blockers \\
\hline ARDS & acute respiratory distress syndrome \\
\hline ICU & intensive care unit \\
\hline ADAM-17 & ADAM metallopeptidase domain 17 \\
\hline TMPRSS2 & Transmembrane Serine Protease 2 \\
\hline AR & androgen receptor \\
\hline DHT & dihydrotestosterone \\
\hline LNCaP & activin-sensitive prostate cancer cells \\
\hline ER & endoplasmic reticulum \\
\hline hESC & human embryonic stem cell \\
\hline PD & peptidase domain \\
\hline NAAE & $\mathrm{N}$-(2-aminoethyl)- 1 aziridine-ethanamine \\
\hline $\mathrm{IC}_{50}$ & the half maximal inhibitory concentration \\
\hline $\mathrm{K}_{\mathrm{D}}$ & the calculated affinity \\
\hline IFN & interferon \\
\hline IL & interleukin \\
\hline ERK & extracellular signal-regulated kinase \\
\hline JNK & c-Jun N-terminal kinase \\
\hline IPF & idiopathic pulmonary fibrosis \\
\hline PAH & pulmonary arterial hypertension \\
\hline ALI & acute lung injury \\
\hline LPS & lipopolysaccharide \\
\hline TLR4 & toll-like receptor 4 \\
\hline MAP & mitogen-activated protein \\
\hline ERK/MAPK & extracellular-signal-regulated kinase/mitogen-activated protein kinase \\
\hline NF- $\mathrm{kB}$ & nuclear factor- $\mathrm{kB}$ \\
\hline AMPA & alpha-amino-3-hydroxy-5-methyl-4-isoxazole propionic acid \\
\hline APJ & the apelin receptor \\
\hline SIRT1 & Sirtuin 1 \\
\hline
\end{tabular}




$\begin{array}{ll}\text { AMPK } & \text { AMP-activated protein kinase } \\ \text { T2DM } & \text { Type } 2 \text { diabetes mellitus } \\ \text { ISG } & \text { interferon stimulated gene } \\ \text { fMLP } & \text { N-formylmethionyl-leucyl-phenylalanine } \\ \text { MAS1 } & \text { the G protein-coupled receptor Mas }\end{array}$

\section{References}

1. Zhu, N.; Zhang, D.; Wang, W.; Li, X.; Yang, B.; Song, J.; Zhao, X.; Huang, B.; Shi, W.; Lu, R.; et al. A Novel Coronavirus from Patients with Pneumonia in China, 2019. N. Engl. J. Med. 2020, 382, 727-733. [CrossRef]

2. Statement on the Meeting of the International Health Regulations (2005) Emergency Committee Regarding the Outbreak of Novel Coronavirus (2019-nCoV). Available online: https:/ / www.who.int/zh/news-room/detail/23-01-2020-statement-on-themeeting-of-the-international-health-regulations-(2005)-emergency-committee-regarding-the-outbreak-of-novel-coronavirus(2019-ncov) (accessed on 21 February 2020).

3. Zhou, P.; Yang, X.L.; Wang, X.G.; Hu, B.; Zhang, L.; Zhang, W.; Si, H.R.; Zhu, Y.; Li, B.; Huang, C.L.; et al. A pneumonia outbreak associated with a new coronavirus of probable bat origin. Nature 2020, 579, 270-273. [CrossRef]

4. Lam, T.T.; Jia, N.; Zhang, Y.W.; Shum, M.H.; Jiang, J.F.; Zhu, H.C.; Tong, Y.G.; Shi, Y.X.; Ni, X.B.; Liao, Y.S.; et al. Identifying SARS-CoV-2-related coronaviruses in Malayan pangolins. Nature 2020, 583, 282-285. [CrossRef]

5. Huang, C.; Wang, Y.; Li, X.; Ren, L.; Zhao, J.; Hu, Y.; Zhang, L.; Fan, G.; Xu, J.; Gu, X.; et al. Clinical features of patients infected with 2019 novel coronavirus in Wuhan, China. Lancet 2020, 395, 497-506. [CrossRef]

6. Drosten, C.; Günther, S.; Preiser, W.; van der Werf, S.; Brodt, H.R.; Becker, S.; Rabenau, H.; Panning, M.; Kolesnikova, L.; Fouchier, R.A.; et al. Identification of a novel coronavirus in patients with severe acute respiratory syndrome. N. Engl. J. Med. 2003, 348, 1967-1976. [CrossRef]

7. Pan, F.; Ye, T.; Sun, P.; Gui, S.; Liang, B.; Li, L.; Zheng, D.; Wang, J.; Hesketh, R.L.; Yang, L.; et al. Time Course of Lung Changes at Chest CT during Recovery from Coronavirus Disease 2019 (COVID-19). Radiology 2020, 295, 715-721. [CrossRef]

8. Chai, X.; Hu, L.; Zhang, Y.; Han, W.; Lu, Z.; Ke, A.; Zhou, J.; Shi, G.; Fang, N.; Fan, J.; et al. Specific ACE2 Expression in Cholangiocytes May Cause Liver Damage After 2019-nCoV Infection. BioRxiv 2020. [CrossRef]

9. Han, D.P.; Penn-Nicholson, A.; Cho, M.W. Identification of critical determinants on ACE2 for SARS-CoV entry and development of a potent entry inhibitor. Virology 2006, 350, 15-25. [CrossRef]

10. Unger, T.; Chung, O.; Csikos, T.; Culman, J.; Gallinat, S.; Gohlke, P.; Höhle, S.; Meffert, S.; Stoll, M.; Stroth, U.; et al. Angiotensin receptors. J. Hypertens. Suppl. 1996, 14, S95-S103.

11. Wrapp, D.; Wang, N.; Corbett, K.S.; Goldsmith, J.A.; Hsieh, C.L.; Abiona, O.; Graham, B.S.; McLellan, J.S. Cryo-EM structure of the 2019-nCoV spike in the prefusion conformation. Science 2020, 367, 1260-1263. [CrossRef]

12. Yan, R.; Zhang, Y.; Li, Y.; Xia, L.; Guo, Y.; Zhou, Q. Structural basis for the recognition of SARS-CoV-2 by full-length human ACE2. Science 2020, 367, 1444-1448. [CrossRef]

13. Shenoy, V.; Qi, Y.; Katovich, M.J.; Raizada, M.K. ACE2, a promising therapeutic target for pulmonary hypertension. Curr. Opin. Pharmacol. 2011, 11, 150-155. [CrossRef]

14. Sayed-Tabatabaei, F.A.; Oostra, B.A.; Isaacs, A.; van Duijn, C.M.; Witteman, J.C. ACE polymorphisms. Circ. Res. 2006, 98, 1123-1133. [CrossRef]

15. Miura, S.; Saku, K.; Karnik, S.S. Molecular analysis of the structure and function of the angiotensin II type 1 receptor. Hypertens. Res. 2003, 26, 937-943. [CrossRef]

16. Wang, X.; Ye, Y.; Gong, H.; Wu, J.; Yuan, J.; Wang, S.; Yin, P.; Ding, Z.; Kang, L.; Jiang, Q.; et al. The effects of different angiotensin II type 1 receptor blockers on the regulation of the ACE-AngII-AT1 and ACE2-Ang(1-7)-Mas axes in pressure overload-induced cardiac remodeling in male mice. J. Mol. Cell. Cardiol. 2016, 97, 180-190. [CrossRef]

17. Donoghue, M.; Hsieh, F.; Baronas, E.; Godbout, K.; Gosselin, M.; Stagliano, N.; Donovan, M.; Woolf, B.; Robison, K.; Jeyaseelan, R.; et al. A novel angiotensin-converting enzyme-related carboxypeptidase (ACE2) converts angiotensin I to angiotensin 1-9. Circ. Res. 2000, 87, E1-E9. [CrossRef]

18. Crackower, M.A.; Sarao, R.; Oudit, G.Y.; Yagil, C.; Kozieradzki, I.; Scanga, S.E.; Oliveira-dos-Santos, A.J.; da Costa, J.; Zhang, L.; Pei, Y.; et al. Angiotensin-converting enzyme 2 is an essential regulator of heart function. Nature 2002, 417, 822-828. [CrossRef]

19. Santos, R.A.; Simoes e Silva, A.C.; Maric, C.; Silva, D.M.; Machado, R.P.; de Buhr, I.; Heringer-Walther, S.; Pinheiro, S.V.; Lopes, M.T.; Bader, M.; et al. Angiotensin-(1-7) is an endogenous ligand for the G protein-coupled receptor Mas. Proc. Natl. Acad. Sci. USA 2003, 100, 8258-8263. [CrossRef]

20. Ferrario, C.M.; Chappell, M.C.; Tallant, E.A.; Brosnihan, K.B.; Diz, D.I. Counterregulatory actions of angiotensin-(1-7). Hypertension 1997, 30, 535-541. [CrossRef]

21. Passos-Silva, D.G.; Brandan, E.; Santos, R.A. Angiotensins as therapeutic targets beyond heart disease. Trends Pharmacol. Sci. 2015, 36, 310-320. [CrossRef]

22. Lv, L.L.; Liu, B.C. Role of non-classical renin-angiotensin system axis in renal fibrosis. Front. Physiol. 2015, 6, 117. [CrossRef]

23. Chappell, M.C.; Pirro, N.T.; Sykes, A.; Ferrario, C.M. Metabolism of angiotensin-(1-7) by angiotensin-converting enzyme. Hypertension 1998, 31, 362-367. [CrossRef] 
24. Turner, A.J.; Hooper, N.M. The angiotensin-converting enzyme gene family: Genomics and pharmacology. Trends Pharmacol. Sci. 2002, 23, 177-183. [CrossRef]

25. Soler, M.J.; Barrios, C.; Oliva, R.; Batlle, D. Pharmacologic modulation of ACE2 expression. Curr. Hypertens. Rep. 2008, 10, 410-414. [CrossRef]

26. Gembardt, F.; Sterner-Kock, A.; Imboden, H.; Spalteholz, M.; Reibitz, F.; Schultheiss, H.P.; Siems, W.E.; Walther, T. Organ-specific distribution of ACE2 mRNA and correlating peptidase activity in rodents. Peptides 2005, 26, 1270-1277. [CrossRef]

27. Hamming, I.; Timens, W.; Bulthuis, M.L.; Lely, A.T.; Navis, G.; van Goor, H. Tissue distribution of ACE2 protein, the functional receptor for SARS coronavirus. A first step in understanding SARS pathogenesis. J. Pathol. 2004, 203, 631-637. [CrossRef]

28. Kuba, K.; Imai, Y.; Rao, S.; Gao, H.; Guo, F.; Guan, B.; Huan, Y.; Yang, P.; Zhang, Y.; Deng, W.; et al. A crucial role of angiotensin converting enzyme 2 (ACE2) in SARS coronavirus-induced lung injury. Nat. Med. 2005, 11, 875-879. [CrossRef]

29. Jakovac, H. COVID-19: Is the ACE2 just a foe? American journal of physiology. Am. J. Physiol. Lung Cell. Mol. Physiol. 2020, 318, L1025-L1026. [CrossRef]

30. Vabret, N.; Britton, G.J.; Gruber, C.; Hegde, S.; Kim, J.; Kuksin, M.; Levantovsky, R.; Malle, L.; Moreira, A.; Park, M.D.; et al. Immunology of COVID-19: Current State of the Science. Immunity 2020, 52, 910-941. [CrossRef]

31. Hashimoto, T.; Perlot, T.; Rehman, A.; Trichereau, J.; Ishiguro, H.; Paolino, M.; Sigl, V.; Hanada, T.; Hanada, R.; Lipinski, S.; et al. ACE2 links amino acid malnutrition to microbial ecology and intestinal inflammation. Nature 2012, 487, 477-481. [CrossRef]

32. Li, Z.; Wu, M.; Yao, J.; Guo, J.; Liao, X.; Song, S.; Li, J.; Duan, G.; Zhou, Y.; Wu, X.; et al. Caution on Kidney Dysfunctions of COVID-19 Patients. medRxiv 2020. [CrossRef]

33. Rice, G.I.; Jones, A.L.; Grant, P.J.; Carter, A.M.; Turner, A.J.; Hooper, N.M. Circulating activities of angiotensin-converting enzyme, its homolog, angiotensin-converting enzyme 2, and neprilysin in a family study. Hypertension 2006, 48, 914-920. [CrossRef]

34. Anguiano, L.; Riera, M.; Pascual, J.; Soler, M.J. Circulating ACE2 in Cardiovascular and Kidney Diseases. Curr. Med. Chem. 2017, 24, 3231-3241. [CrossRef]

35. Burrell, L.M.; Burchill, L.; Dean, R.G.; Griggs, K.; Patel, S.K.; Velkoska, E. Chronic kidney disease: Cardiac and renal angiotensinconverting enzyme (ACE) 2 expression in rats after subtotal nephrectomy and the effect of ACE inhibition. Exp. Physiol. 2012, 97, 477-485. [CrossRef]

36. Narula, S.; Yusuf, S.; Chong, M.; Ramasundarahettige, C.; Rangarajan, S.; Bangdiwala, S.I.; van Eikels, M.; Leineweber, K.; Wu, A.; Pigeyre, M.; et al. Plasma ACE2 and risk of death or cardiometabolic diseases: A case-cohort analysis. Lancet 2020, 396, 968-976. [CrossRef]

37. Iwata, M.; Silva Enciso, J.E.; Greenberg, B.H. Selective and specific regulation of ectodomain shedding of angiotensin-converting enzyme 2 by tumor necrosis factor alpha-converting enzyme. Am. J. Physiol. Cell Physiol. 2009, 297, C1318-C1329. [CrossRef]

38. Sama, I.E.; Ravera, A.; Santema, B.T.; van Goor, H.; Ter Maaten, J.M.; Cleland, J.G.F.; Rienstra, M.; Friedrich, A.W.; Samani, N.J.; $\mathrm{Ng}$, L.L.; et al. Circulating plasma concentrations of angiotensin-converting enzyme 2 in men and women with heart failure and effects of renin-angiotensin-aldosterone inhibitors. Eur. Heart J. 2020, 41, 1810-1817. [CrossRef]

39. Song, H.; Seddighzadeh, B.; Cooperberg, M.R.; Huang, F.W. Expression of ACE2, the SARS-CoV-2 Receptor, and TMPRSS2 in Prostate Epithelial Cells. Eur. Urol. 2020, 78, 296-298. [CrossRef]

40. Wu, S.; Miao, L.; Zhou, Q.; Gao, C.; Liu, J.; Zhan, Q.; Guo, B.; Li, F.; Wang, Y.; Xu, H.; et al. Suppression of Androgen Receptor (AR)-ACE2/TMPRSS2 Axis by AR Antagonists May Be Therapeutically Beneficial for Male COVID-19 Patients. Available online: http:/ / dx.doi.org/10.2139/ssrn.3580526 (accessed on 18 July 2020).

41. Gallagher, T.M.; Buchmeier, M.J. Coronavirus spike proteins in viral entry and pathogenesis. Virology 2001, 279, 371-374. [CrossRef]

42. Simmons, G.; Zmora, P.; Gierer, S.; Heurich, A.; Pöhlmann, S. Proteolytic activation of the SARS-coronavirus spike protein: Cutting enzymes at the cutting edge of antiviral research. Antivir. Res. 2013, 100, 605-614. [CrossRef]

43. Li, F.; Li, W.; Farzan, M.; Harrison, S.C. Structure of SARS coronavirus spike receptor-binding domain complexed with receptor. Science 2005, 309, 1864-1868. [CrossRef]

44. Menachery, V.D.; Dinnon, K.H., 3rd; Yount, B.L., Jr.; McAnarney, E.T.; Gralinski, L.E.; Hale, A.; Graham, R.L.; Scobey, T.; Anthony, S.J.; Wang, L.; et al. Trypsin Treatment Unlocks Barrier for Zoonotic Bat Coronavirus Infection. J. Virol. $2020,94$. [CrossRef]

45. Simmons, G.; Gosalia, D.N.; Rennekamp, A.J.; Reeves, J.D.; Diamond, S.L.; Bates, P. Inhibitors of cathepsin L prevent severe acute respiratory syndrome coronavirus entry. Proc. Natl. Acad. Sci. USA 2005, 102, 11876-11881. [CrossRef]

46. Iwata-Yoshikawa, N.; Okamura, T.; Shimizu, Y.; Hasegawa, H.; Takeda, M.; Nagata, N. TMPRSS2 Contributes to Virus Spread and Immunopathology in the Airways of Murine Models after Coronavirus Infection. J. Virol. 2019, 93. [CrossRef]

47. Hoffmann, M.; Kleine-Weber, H.; Krüger, N.; Müller, M.; Drosten, C.; Pöhlmann, S. The novel coronavirus 2019 (2019-nCoV) uses the SARS-coronavirus receptor ACE2 and the cellular protease TMPRSS2 for entry into target cells. bioRxiv 2020. [CrossRef]

48. Zhou, Y.; Vedantham, P.; Lu, K.; Agudelo, J.; Carrion, R., Jr.; Nunneley, J.W.; Barnard, D.; Pöhlmann, S.; McKerrow, J.H.; Renslo, A.R.; et al. Protease inhibitors targeting coronavirus and filovirus entry. Antivir. Res. 2015, 116, 76-84. [CrossRef]

49. Gheblawi, M.; Wang, K.; Viveiros, A.; Nguyen, Q.; Zhong, J.C.; Turner, A.J.; Raizada, M.K.; Grant, M.B.; Oudit, G.Y. AngiotensinConverting Enzyme 2: SARS-CoV-2 Receptor and Regulator of the Renin-Angiotensin System: Celebrating the 20th Anniversary of the Discovery of ACE2. Circ. Res. 2020, 126, 1456-1474. [CrossRef] 
50. Shang, J.; Ye, G.; Shi, K.; Wan, Y.; Luo, C.; Aihara, H.; Geng, Q.; Auerbach, A.; Li, F. Structural basis of receptor recognition by SARS-CoV-2. Nature 2020, 581, 221-224. [CrossRef]

51. Samuel, R.M.; Majd, H.; Richter, M.N.; Ghazizadeh, Z.; Zekavat, S.M.; Navickas, A.; Ramirez, J.T.; Asgharian, H.; Simoneau, C.R.; Bonser, L.R.; et al. Androgen Signaling Regulates SARS-CoV-2 Receptor Levels and Is Associated with Severe COVID-19 Symptoms in Men. Cell Stem Cell 2020, 27, 876-889. [CrossRef]

52. Li, W.; Zhang, C.; Sui, J.; Kuhn, J.H.; Moore, M.J.; Luo, S.; Wong, S.K.; Huang, I.C.; Xu, K.; Vasilieva, N.; et al. Receptor and viral determinants of SARS-coronavirus adaptation to human ACE2. EMBO J. 2005, 24, 1634-1643. [CrossRef]

53. Wu, K.; Peng, G.; Wilken, M.; Geraghty, R.J.; Li, F. Mechanisms of host receptor adaptation by severe acute respiratory syndrome coronavirus. J. Biol. Chem. 2012, 287, 8904-8911. [CrossRef]

54. Wan, Y.; Shang, J.; Graham, R.; Baric, R.S.; Li, F. Receptor Recognition by the Novel Coronavirus from Wuhan: An Analysis Based on Decade-Long Structural Studies of SARS Coronavirus. J. Virol. 2020, 94. [CrossRef]

55. Wang, Q.; Zhang, Y.; Wu, L.; Niu, S.; Song, C.; Zhang, Z.; Lu, G.; Qiao, C.; Hu, Y.; Yuen, K.Y.; et al. Structural and Functional Basis of SARS-CoV-2 Entry by Using Human ACE2. Cell 2020, 181, 894-904. [CrossRef]

56. Dales, N.A.; Gould, A.E.; Brown, J.A.; Calderwood, E.F.; Guan, B.; Minor, C.A.; Gavin, J.M.; Hales, P.; Kaushik, V.K.; Stewart, M.; et al. Substrate-based design of the first class of angiotensin-converting enzyme-related carboxypeptidase (ACE2) inhibitors. J. Am. Chem. Soc. 2002, 124, 11852-11853. [CrossRef]

57. Vincent, M.J.; Bergeron, E.; Benjannet, S.; Erickson, B.R.; Rollin, P.E.; Ksiazek, T.G.; Seidah, N.G.; Nichol, S.T. Chloroquine is a potent inhibitor of SARS coronavirus infection and spread. J. Virol. 2005, 2, 69. [CrossRef]

58. Huentelman, M.J.; Zubcevic, J.; Hernández Prada, J.A.; Xiao, X.; Dimitrov, D.S.; Raizada, M.K.; Ostrov, D.A. Structure-based discovery of a novel angiotensin-converting enzyme 2 inhibitor. Hypertension 2004, 44, 903-906. [CrossRef]

59. Tian, X.; Li, C.; Huang, A.; Xia, S.; Lu, S.; Shi, Z.; Lu, L.; Jiang, S.; Yang, Z.; Wu, Y.; et al. Potent binding of 2019 novel coronavirus spike protein by a SARS coronavirus-specific human monoclonal antibody. Emerg. Microbes Infect. 2020, 9, 382-385. [CrossRef]

60. Kassiri, Z.; Zhong, J.; Guo, D.; Basu, R.; Wang, X.; Liu, P.P.; Scholey, J.W.; Penninger, J.M.; Oudit, G.Y. Loss of angiotensinconverting enzyme 2 accelerates maladaptive left ventricular remodeling in response to myocardial infarction. Circ. Heart Fail. 2009, 2, 446-455. [CrossRef]

61. Simões, E.S.A.C.; Teixeira, M.M. ACE inhibition, ACE2 and angiotensin-(1-7) axis in kidney and cardiac inflammation and fibrosis. Pharmacol. Res. 2016, 107, 154-162. [CrossRef]

62. Li, X.; Molina-Molina, M.; Abdul-Hafez, A.; Uhal, V.; Xaubet, A.; Uhal, B.D. Angiotensin converting enzyme-2 is protective but downregulated in human and experimental lung fibrosis. Am. J. Physiol. Lung Cell. Mol. Physiol. 2008, 295, L178-L185. [CrossRef]

63. Imai, Y.; Kuba, K.; Rao, S.; Huan, Y.; Guo, F.; Guan, B.; Yang, P.; Sarao, R.; Wada, T.; Leong-Poi, H.; et al. Angiotensin-converting enzyme 2 protects from severe acute lung failure. Nature 2005, 436, 112-116. [CrossRef]

64. Bogaard, H.J.; Abe, K.; Vonk Noordegraaf, A.; Voelkel, N.F. The right ventricle under pressure: Cellular and molecular mechanisms of right-heart failure in pulmonary hypertension. Chest 2009, 135, 794-804. [CrossRef]

65. Ye, R.; Liu, Z. ACE2 exhibits protective effects against LPS-induced acute lung injury in mice by inhibiting the LPS-TLR4 pathway. Exp. Mol. Pathol. 2020, 113, 104350. [CrossRef]

66. Zou, Z.; Yan, Y.; Shu, Y.; Gao, R.; Sun, Y.; Li, X.; Ju, X.; Liang, Z.; Liu, Q.; Zhao, Y.; et al. Angiotensin-converting enzyme 2 protects from lethal avian influenza A H5N1 infections. Nat. Commun. 2014, 5, 3594. [CrossRef]

67. Yang, P.; Gu, H.; Zhao, Z.; Wang, W.; Cao, B.; Lai, C.; Yang, X.; Zhang, L.; Duan, Y.; Zhang, S.; et al. Angiotensin-converting enzyme 2 (ACE2) mediates influenza H7N9 virus-induced acute lung injury. Sci. Rep. 2014, 4, 7027. [CrossRef]

68. Perlot, T.; Penninger, J.M. ACE2-From the renin-angiotensin system to gut microbiota and malnutrition. Microbes. Infect. 2013, 15, 866-873. [CrossRef]

69. Song, B.; Jin, H.; Yu, X.; Zhang, Z.; Yu, H.; Ye, J.; Xu, Y.; Zhou, T.; Oudit, G.Y.; Ye, J.Y.; et al. Angiotensin-converting enzyme 2 attenuates oxidative stress and VSMC proliferation via the JAK2/STAT3/ SOCS3 and profilin-1/MAPK signaling pathways. Regul. Pept. 2013, 185, 44-51. [CrossRef]

70. Koka, V.; Huang, X.R.; Chung, A.C.; Wang, W.; Truong, L.D.; Lan, H.Y. Angiotensin II up-regulates angiotensin I-converting enzyme (ACE), but down-regulates ACE2 via the AT1-ERK/p38 MAP kinase pathway. Am. J. Pathol. 2008, 172, 1174-1183. [CrossRef]

71. Takase, O.; Marumo, T.; Imai, N.; Hirahashi, J.; Takayanagi, A.; Hishikawa, K.; Hayashi, M.; Shimizu, N.; Fujita, T.; Saruta, T. NF-kappaB-dependent increase in intrarenal angiotensin II induced by proteinuria. Kidney Int. 2005, 68, 464-473. [CrossRef]

72. Oparil, S.; Silfani, T.N.; Walker, J.F. Role of angiotensin receptor blockers as monotherapy in reaching blood pressure goals. Am. J. Hypertens. 2005, 18, 287-294. [CrossRef]

73. Furuhashi, M.; Moniwa, N.; Mita, T.; Fuseya, T.; Ishimura, S.; Ohno, K.; Shibata, S.; Tanaka, M.; Watanabe, Y.; Akasaka, H.; et al. Urinary angiotensin-converting enzyme 2 in hypertensive patients may be increased by olmesartan, an angiotensin II receptor blocker. Am. J. Hypertens. 2015, 28, 15-21. [CrossRef]

74. Ocaranza, M.P.; Godoy, I.; Jalil, J.E.; Varas, M.; Collantes, P.; Pinto, M.; Roman, M.; Ramirez, C.; Copaja, M.; Diaz-Araya, G.; et al. Enalapril attenuates downregulation of Angiotensin-converting enzyme 2 in the late phase of ventricular dysfunction in myocardial infarcted rat. Hypertension 2006, 48, 572-578. [CrossRef]

75. Aronson, J.K.; Ferner, R.E. Drugs and the renin-angiotensin system in covid-19. BMJ 2020, 369, m1313. [CrossRef] 
76. Shyh, G.I.; Nawarskas, J.J.; Cheng-Lai, A. Angiotensin-Converting Enzyme Inhibitors and Angiotensin Receptor Blockers in Patients with Coronavirus Disease 2019: Friend or Foe? Cardiol. Rev. 2020, 28, 213-216. [CrossRef]

77. Vaduganathan, M.; Vardeny, O.; Michel, T.; McMurray, J.J.V.; Pfeffer, M.A.; Solomon, S.D. Renin-Angiotensin- Aldosterone System Inhibitors in Patients with Covid-19. N. Engl. J. Med. 2020, 382, 1653-1659. [CrossRef]

78. Keidar, S.; Gamliel-Lazarovich, A.; Kaplan, M.; Pavlotzky, E.; Hamoud, S.; Hayek, T.; Karry, R.; Abassi, Z. Mineralocorticoid receptor blocker increases angiotensin-converting enzyme 2 activity in congestive heart failure patients. Circ. Res. 2005, 97, 946-953. [CrossRef]

79. Xu, J.; Yang, J.; Chen, J.; Luo, Q.; Zhang, Q.; Zhang, H. Vitamin D alleviates lipopolysaccharide-induced acute lung injury via regulation of the renin-angiotensin system. Mol. Med. Rep. 2017, 16, 7432-7438. [CrossRef]

80. Siddiqui, M.; Manansala, J.S.; Abdulrahman, H.A.; Nasrallah, G.K.; Smatti, M.K.; Younes, N.; Althani, A.A.; Yassine, H.M. Immune Modulatory Effects of Vitamin D on Viral Infections. Nutrients 2020, 12, 2879. [CrossRef]

81. Malek Mahdavi, A. A brief review of interplay between vitamin D and angiotensin-converting enzyme 2: Implications for a potential treatment for COVID-19. Rev. Med. Virol. 2020, 30, e2119. [CrossRef]

82. Sato, T.; Suzuki, T.; Watanabe, H.; Kadowaki, A.; Fukamizu, A.; Liu, P.P.; Kimura, A.; Ito, H.; Penninger, J.M.; Imai, Y.; et al. Apelin is a positive regulator of ACE2 in failing hearts. J. Clin. Investig. 2013, 123, 5203-5211. [CrossRef]

83. Wang, W.; Shen, M.; Fischer, C.; Basu, R.; Hazra, S.; Couvineau, P.; Paul, M.; Wang, F.; Toth, S.; Mix, D.S.; et al. Apelin protects against abdominal aortic aneurysm and the therapeutic role of neutral endopeptidase resistant apelin analogs. Proc. Natl. Acad. Sci. USA 2019, 116, 13006-13015. [CrossRef]

84. Wang, W.; McKinnie, S.M.; Farhan, M.; Paul, M.; McDonald, T.; McLean, B.; Llorens-Cortes, C.; Hazra, S.; Murray, A.G.; Vederas, J.C.; et al. Angiotensin-Converting Enzyme 2 Metabolizes and Partially Inactivates Pyr-Apelin-13 and Apelin-17: Physiological Effects in the Cardiovascular System. Hypertension 2016, 68, 365-377. [CrossRef]

85. Clarke, N.E.; Belyaev, N.D.; Lambert, D.W.; Turner, A.J. Epigenetic regulation of angiotensin-converting enzyme 2 (ACE2) by SIRT1 under conditions of cell energy stress. Clin. Sci. 2014, 126, 507-516. [CrossRef]

86. Zhang, Z.Z.; Cheng, Y.W.; Jin, H.Y.; Chang, Q.; Shang, Q.H.; Xu, Y.L.; Chen, L.X.; Xu, R.; Song, B.; Zhong, J.C. The sirtuin 6 prevents angiotensin II-mediated myocardial fibrosis and injury by targeting AMPK-ACE2 signaling. Oncotarget 2017, 8, 72302-72314. [CrossRef]

87. Xia, N.; Daiber, A.; Förstermann, U.; Li, H. Antioxidant effects of resveratrol in the cardiovascular system. Br. J. Pharmacol. 2017, 174, 1633-1646. [CrossRef]

88. Yu, H.; Pan, W.; Huang, H.; Chen, J.; Sun, B.; Yang, L.; Zhu, P. Screening Analysis of Sirtuins Family Expression on AntiInflammation of Resveratrol in Endothelial Cells. Med. Sci. Monit. 2019, 25, 4137-4148. [CrossRef]

89. de Lang, A.; Osterhaus, A.D.; Haagmans, B.L. Interferon-gamma and interleukin-4 downregulate expression of the SARS coronavirus receptor ACE2 in Vero E6 cells. Virology 2006, 353, 474-481. [CrossRef]

90. Ziegler, C.G.K.; Allon, S.J.; Nyquist, S.K.; Mbano, I.M.; Miao, V.N.; Tzouanas, C.N.; Cao, Y.; Yousif, A.S.; Bals, J.; Hauser, B.M.; et al. SARS-CoV-2 Receptor ACE2 Is an Interferon-Stimulated Gene in Human Airway Epithelial Cells and Is Detected in Specific Cell Subsets across Tissues. Cell 2020, 181, 1016-1035. [CrossRef]

91. Chen, N.; Zhou, M.; Dong, X.; Qu, J.; Gong, F.; Han, Y.; Qiu, Y.; Wang, J.; Liu, Y.; Wei, Y.; et al. Epidemiological and clinical characteristics of 99 cases of 2019 novel coronavirus pneumonia in Wuhan, China: A descriptive study. Lancet 2020, 395, 507-513. [CrossRef]

92. Zhu, Y.Z.; Zhu, Y.C.; Li, J.; Schäfer, H.; Schmidt, W.; Yao, T.; Unger, T. Effects of losartan on haemodynamic parameters and angiotensin receptor mRNA levels in rat heart after myocardial infarction. J. Renin Angiotensin Aldosterone Syst. 2000, 1, $257-262$. [CrossRef]

93. Zhu, Y.Z.; Zhu, Y.C.; Wang, Z.J.; Lu, Q.; Lee, H.S.; Unger, T. Time-dependent apoptotic development and pro-apoptotic genes expression in rat heart after myocardial infarction. Jpn. J. Pharmacol. 2001, 86, 355-358. [CrossRef]

94. Guy, J.L.; Lambert, D.W.; Warner, F.J.; Hooper, N.M.; Turner, A.J. Membrane-associated zinc peptidase families: Comparing ACE and ACE2. Biochim. Biophys. Acta 2005, 1751, 2-8. [CrossRef]

95. Xu, Z.; Shi, L.; Wang, Y.; Zhang, J.; Huang, L.; Zhang, C.; Liu, S.; Zhao, P.; Liu, H.; Zhu, L.; et al. Pathological findings of COVID-19 associated with acute respiratory distress syndrome. Lancet Respir. Med. 2020, 8, 420-422. [CrossRef]

96. Ding, Y.; Wang, H.; Shen, H.; Li, Z.; Geng, J.; Han, H.; Cai, J.; Li, X.; Kang, W.; Weng, D.; et al. The clinical pathology of severe acute respiratory syndrome (SARS): A report from China. J. Pathol. 2003, 200, 282-289. [CrossRef]

97. Ng, D.L.; Al Hosani, F.; Keating, M.K.; Gerber, S.I.; Jones, T.L.; Metcalfe, M.G.; Tong, S.; Tao, Y.; Alami, N.N.; Haynes, L.M.; et al. Clinicopathologic, Immunohistochemical, and Ultrastructural Findings of a Fatal Case of Middle East Respiratory Syndrome Coronavirus Infection in the United Arab Emirates, April 2014. Am. J. Pathol. 2016, 186, 652-658. [CrossRef]

98. Raiden, S.; Nahmod, K.; Nahmod, V.; Semeniuk, G.; Pereira, Y.; Alvarez, C.; Giordano, M.; Geffner, J.R. Nonpeptide antagonists of AT1 receptor for angiotensin II delay the onset of acute respiratory distress syndrome. J. Pharmacol. Exp. Ther. 2002, 303, 45-51. [CrossRef]

99. Ferrario, C.M.; Jessup, J.; Chappell, M.C.; Averill, D.B.; Brosnihan, K.B.; Tallant, E.A.; Diz, D.I.; Gallagher, P.E. Effect of angiotensinconverting enzyme inhibition and angiotensin II receptor blockers on cardiac angiotensin-converting enzyme 2. Circulation 2005, 111, 2605-2610. [CrossRef] 
100. Ishiyama, Y.; Gallagher, P.E.; Averill, D.B.; Tallant, E.A.; Brosnihan, K.B.; Ferrario, C.M. Upregulation of angiotensin-converting enzyme 2 after myocardial infarction by blockade of angiotensin II receptors. Hypertension 2004, 43, 970-976. [CrossRef]

101. Ferrario, C.M.; Jessup, J.; Gallagher, P.E.; Averill, D.B.; Brosnihan, K.B.; Ann Tallant, E.; Smith, R.D.; Chappell, M.C. Effects of renin-angiotensin system blockade on renal angiotensin-(1-7) forming enzymes and receptors. Kidney Int. 2005, 68, 2189-2196. [CrossRef]

102. Sriram, K.; Loomba, R.; Insel, P.A. Targeting the renin-angiotensin signaling pathway in COVID-19: Unanswered questions, opportunities, and challenges. Proc. Natl. Acad. Sci. USA 2020, 117, 29274-29282. [CrossRef]

103. Wang, J.; Zhao, S.; Liu, M.; Zhao, Z.; Xu, Y.; Wang, P.; Lin, M.; Xu, Y.; Huang, B.; Zuo, X.; et al. ACE2 expression by colonic epithelial cells is associated with viral infection, immunity and energy metabolism. medRxiv 2020. [CrossRef]

104. Monteil, V.; Kwon, H.; Prado, P.; Hagelkrüys, A.; Wimmer, R.A.; Stahl, M.; Leopoldi, A.; Garreta, E.; Hurtado Del Pozo, C.; Prosper, F.; et al. Inhibition of SARS-CoV-2 Infections in Engineered Human Tissues Using Clinical-Grade Soluble Human ACE2. Cell 2020, 181, 905-913. [CrossRef]

105. Arendse, L.B.; Danser, A.H.J.; Poglitsch, M.; Touyz, R.M.; Burnett, J.C., Jr.; Llorens-Cortes, C.; Ehlers, M.R.; Sturrock, E.D. Novel Therapeutic Approaches Targeting the Renin-Angiotensin System and Associated Peptides in Hypertension and Heart Failure. Pharmacol. Rev. 2019, 71, 539-570. [CrossRef]

106. Khan, A.; Benthin, C.; Zeno, B.; Albertson, T.E.; Boyd, J.; Christie, J.D.; Hall, R.; Poirier, G.; Ronco, J.J.; Tidswell, M.; et al. A pilot clinical trial of recombinant human angiotensin-converting enzyme 2 in acute respiratory distress syndrome. Crit. Care 2017, 21, 234. [CrossRef]

107. Minato, T.; Nirasawa, S.; Sato, T.; Yamaguchi, T.; Hoshizaki, M.; Inagaki, T.; Nakahara, K.; Yoshihashi, T.; Ozawa, R.; Yokota, S.; et al. B38-CAP is a bacteria-derived ACE2-like enzyme that suppresses hypertension and cardiac dysfunction. Nat. Commun. 2020, 11, 1058. [CrossRef]

108. Chan, K.K.; Dorosky, D.; Sharma, P.; Abbasi, S.A.; Dye, J.M.; Kranz, D.M.; Herbert, A.S.; Procko, E. Engineering human ACE2 to optimize binding to the spike protein of SARS coronavirus 2. Science 2020, 369, 1261-1265. [CrossRef]

109. Pang, X.; Cui, Y.; Zhu, Y. Recombinant human ACE2: Potential therapeutics of SARS-CoV-2 infection and its complication. Acta Pharmacol Sin. 2020, 41, 1255-1257. [CrossRef] 